\title{
OBSERVATIONS OF CARBON DIOXIDE IN CONSCIOUS AND ANAESTHETIZED SUBJECTS USING THE LISTON-BECKER INFRA-RED ANALYSER
}

\author{
William G. Cullen, m.D , ${ }^{*}$ G. Fredertck Brindle, M.D., ${ }^{*}$ and \\ Harold R. GriFfith, M.D., ${ }^{*}$ F.R.C.P.(c), F.F.A.R.C.S. ${ }^{*}$
}

The PHYSTOLOGICAL ROLE of carbon dioxide has long been appreciated. The gas is of paramount importance in the control of both the respiration and the circullation. Normally the tensinn of carbon dioxide in the fluids of the body is maintained within narrow limits ( $\mathrm{L}$ ).

However, during anaesthesia these narrow limits are certainly not always maintained. In fact, the finding of marked degrees of respiratory acidosis, owing to the build-up of excessive amounts of carbon dioxide during anąesthesia, is now commonly reported $(2,3,4,5,6,7,8)$.

Although carbon dioxide is the prime factor in producing acidosis, the retention of other metabolic waste products during anaesthesia may also contribute to the clinical picture (9). Their significance requires elucidation.

Recently Bourne $(10)$ and others $(3,7,11)$, including the authors $(12)$, have reviewed the literature on the effects of an excess of carbon dioxide during anaesthesia.

Some ten years ago the late Kenneth Heard of Toronto said that "the measure of a good anaesthetist is his ablity to maintain good oxygenation in his patient" (13). If he were here with us today, I am certain that he would be the first one to modify his definition to include "the avoidance of an accumulation of carbon dioxide and other waste products"

The acquisition of a Liston-Becker infra-red analyser ${ }^{1}$ provided us with a practical physical method of analysing the respired gas mixtures for their carbon dioxide content. Our particular sampling cell (the standard cell on Model 16) was found to be most suitable for contnuous sampling of respired gases. The content of carbon dioxide of a sample of mixed gases which is passing through the cell is read on an ink-writing recorder in percentages of carbon dioxide. Thus from moment to moment, from breath to breath, from inspiration to expiration, or from even the beginning to the end of either, the actual content of carbon dioxide can be observed on the recorder. This recorder has three speeds which allow it to measure accurately the tirne factor (i.e., 5,15 , or 30 seconds per centimetre of paper; Fig. 1) The speed can be chosen according to the rate of respiration or the details of pattern desired in the study. Before and after each test, a calibration trac ng was obtained by using as a standard a sample of carbon dioxide provided by the manufacturer, for example, 10.1 per cent carbon dioxide and 89.9 per cent oxygen. The range of the recorder was arbitrarily set

"Department of Anaesthesıa, Queen Elizabeth Hospital, and McGill University, Montreal.

1Donated to the Department of Anaesthesia, McGill University, by Burroughs Wellcome $\&$ Co of Canada. 


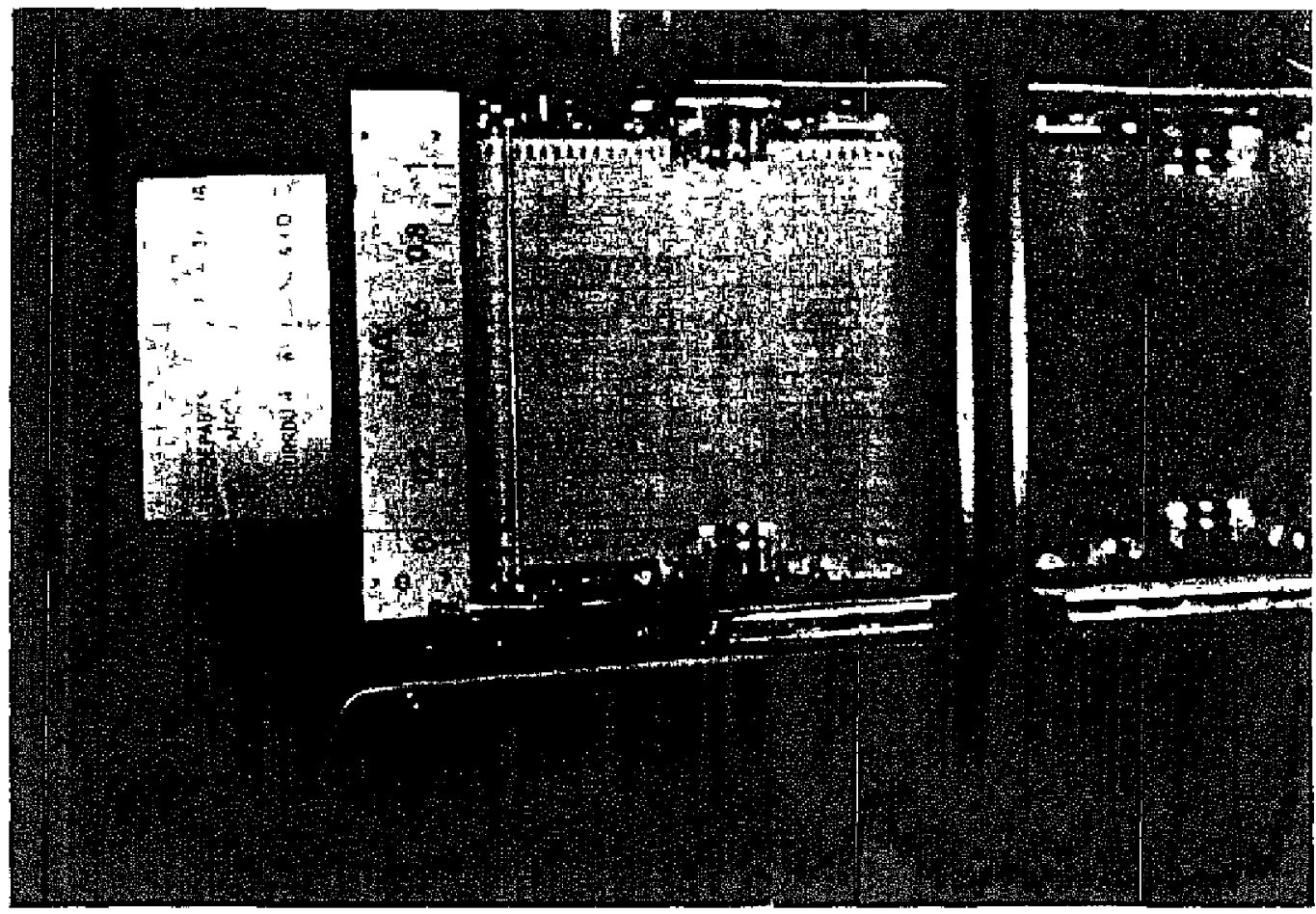

Figune 1 Ink-wnting recorder for the Liston-Becker infrri-red analyser

trom 0 to 10 per cent caubon dioxide, as we found this to be a convenient range lor our observations

We were interested to know how much calbon dioxide was present in the inspued gas, as well as the expred gas, during various (commonly accepted) anaesthetic technques $(19,20)$ We had a method of montoring not only the actual technques but also the same technque using different gas machines Natually, absorption methods were first looked upon wth a critical eye Then the particular chemical used as an absorber was studied, $1 \mathrm{e}$, various types of lime

Probably the most important part of our study was related to the problem of determuning the adequacy of any method of ventulation Spontaneous ventilation (Sp V) was compared with manually contiolled ventulation (M C V) and the latter was compared with automatically contiolled ventiation ( $\mathrm{ACV}$ ) in so far as the content of carbon doxide in the sespured gases conld serve as an index of efficiency

Carbon dioxide accumulation is not confined to any one technque of anaesthetic admunstration but may occur with most, if not all, technuques $(15,18)$, for example, the prolonged effects of succinylcholine ase piobably due to car bon dioxide accumulation $(16,17)$

Although most of our observations were made on anaesthetzed patients, conscious volunteers were also used to obtain the carbon droxide patterns Only about fifty such patterns have been obtamed, so that thas report should only be considered as a preliminary one However, a close study of the avalable tracings has proven very interesting and may challenge some of our clinical impressions 


\section{Expratory Only}

Methods of Sampline

The Liston-Becker sampling cell is placed in the expiratcry circunt of a circle absorption system just as it leaves the Y-connector at the raask or endotracheal tube (Fig 2) The tracing provides a measurement of the carbon dioxide con-

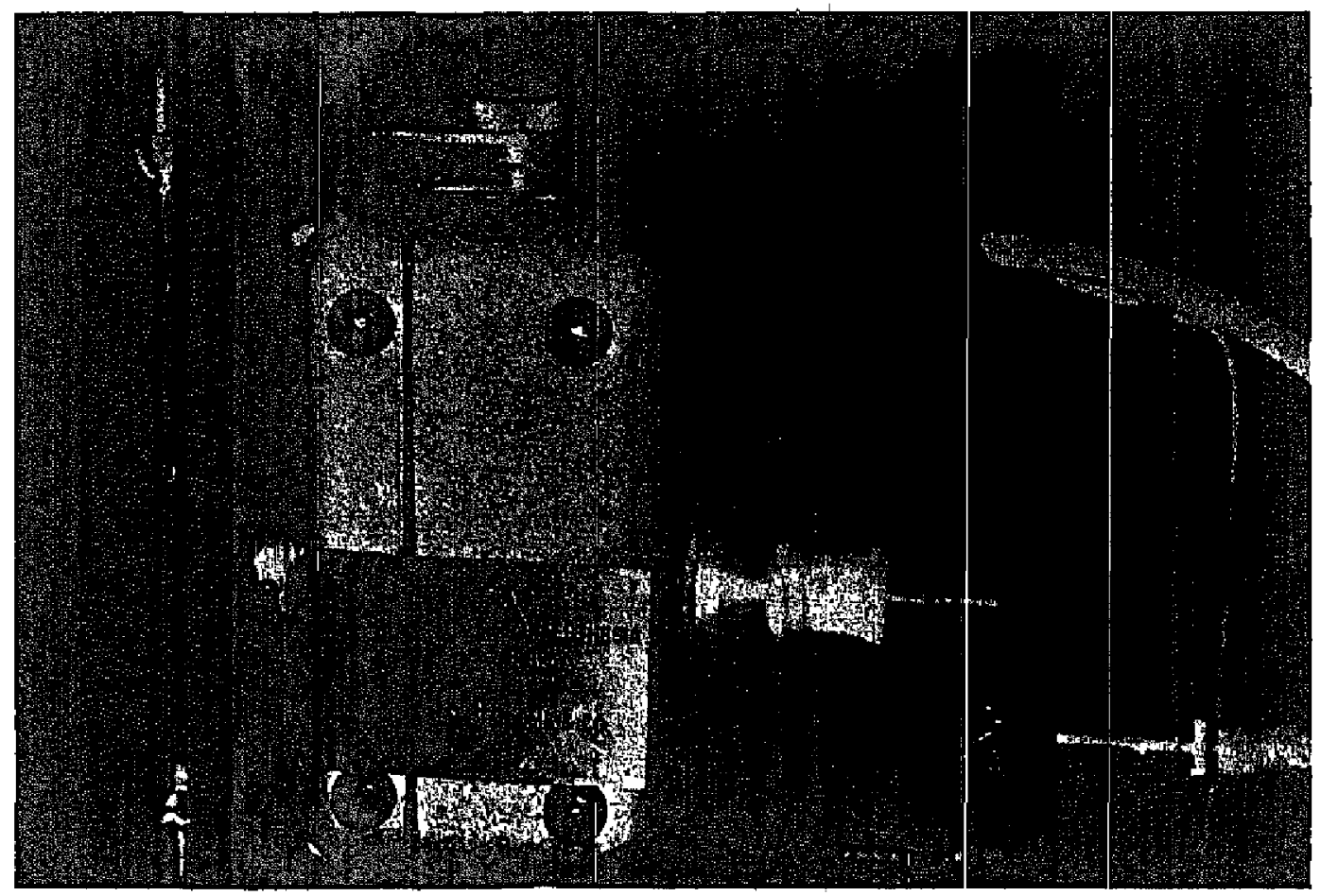

Figure 2 The Liston-Becker samplung cell placed in the expiratory curcuit for expiratory sampling only

tent of the muxed expired gases. We are partucularly interested in knowing the content of the end-expiratory or end-tidal sample, as thus value is as close to that of the alveolar arr as can be determined The curve rises to a plateau which is terminated by an additıonal short rise to a "point" immediately prior to the inspiratory phase (Fig 3) This last "point" on the wave is thought then to represent the alveolar carbon dioxide content (14)

Intrally we thought that this method of sampling would be the nost accurate way to determme the carbon dioxide content of the end-expuratory sample However, it seemed that the fresh gases, if entering at a high flow rate, could readily pass though the $Y$-connector and contammate the sample; in the cell In addition, if inspiration were assisted or contiolled a greater spill-over into the expiratory arm would occur from the inspiratory side Although such contamination of the sample could readily occur with anaesthetized subjects, it was also possible in conscious ones, even though to a lesser degree

\section{Inspratory Only}

The Liston-Becker samplng cell is placed in the insprratory curcuit at the inspiratory valve of the machine It can also be placed next to the "Hico' 


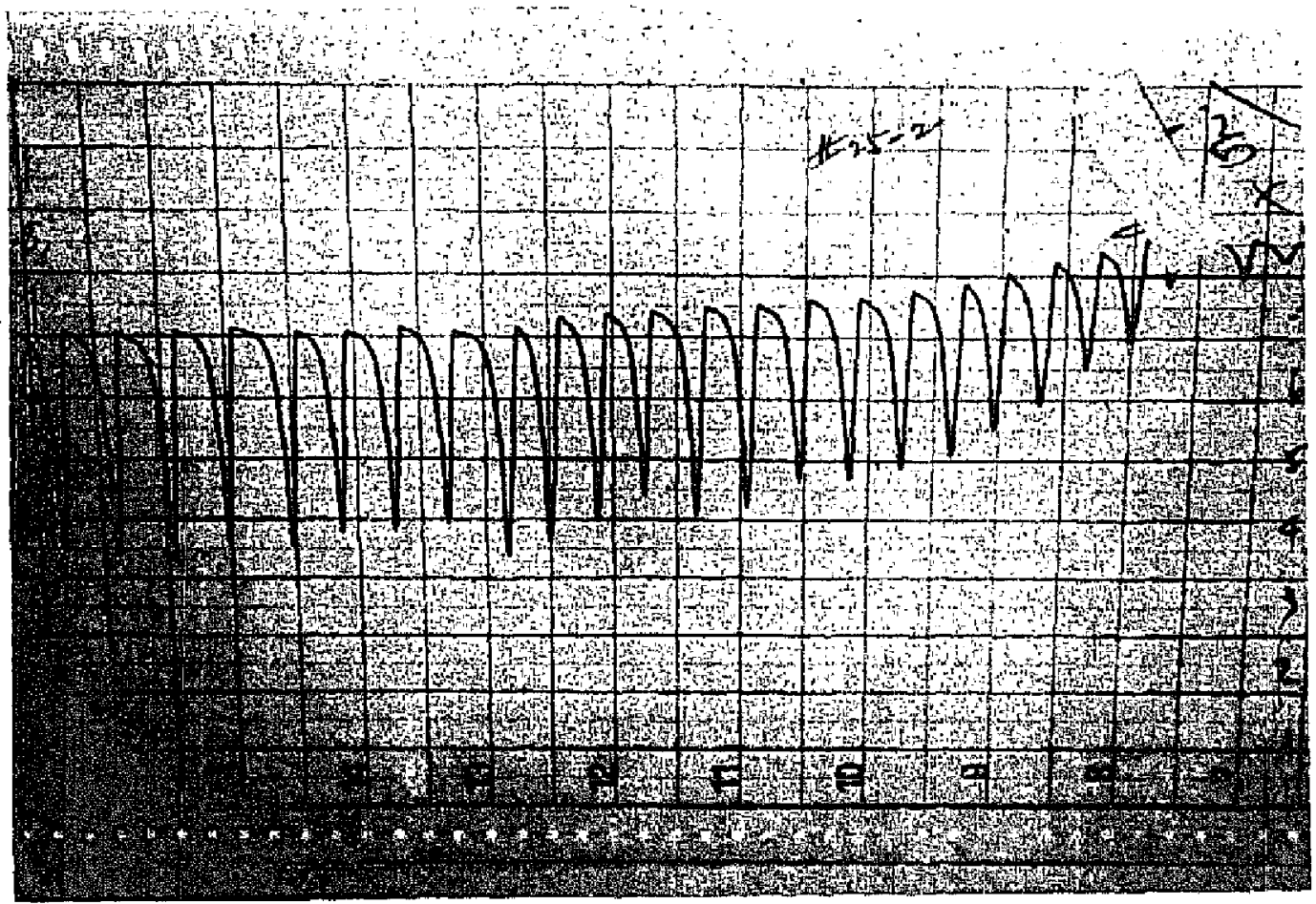

Figure 3 ( Tracing no, 25-2). Tracing obtained during expiratory sampling, showing alveolar carbon dioxide values between 6.7 and 7.5 per cent at the upper limits of the pattern.

detector $^{2}$ when the latter is adjacent to the inspiratory valve. This detector is a simple device introduced by Draper (21) which determines the concentration of carbon dioxide in the inspired mixture, utilizing the acid-base indicator, bromcresol purple.

Tracing no. 6 (Fig. 4) shows the inspiratory pattern ubtained with a conscious subject when the degree of absorption of the machine was deliberately changed. The levels of carbon dioxide at which the "Hico" detector changed in colour were recorded.

\section{Indicator Colour}

Deep purple - Faded 0
Deep purple - Faded 0
Purple - Very slightly faded
Purple - Definitely faded
Clear colour - Faded
Straw colour - Faded

\section{Carbon Dioxide Content}

$$
\begin{aligned}
& 0.1-0.2 \% \\
& 1.8-2.0 \% \\
& 3.5-3.7 \% \\
& 4.2-4.4 \% \\
& 5.6-8.0 \% \\
& 8.4-9.0 \%
\end{aligned}
$$

Thus it can be seen that a carbon dioxide level of over 3.5 per cent was necessary to produce even slight fading in this indicator and at least 4.0 per cent was needed to produce a change in colour readily recognized by several observers. Although the efficiency of the "Hico" detector may, at first, not seem adequate, we have clinically found the device to be a helpful indicator of rising carbon dioxide in the inspiratory circuit. At levels of carbon dioxide producing colour

${ }^{2}$ Available from the Ohio Chemical Co. of Canada. 


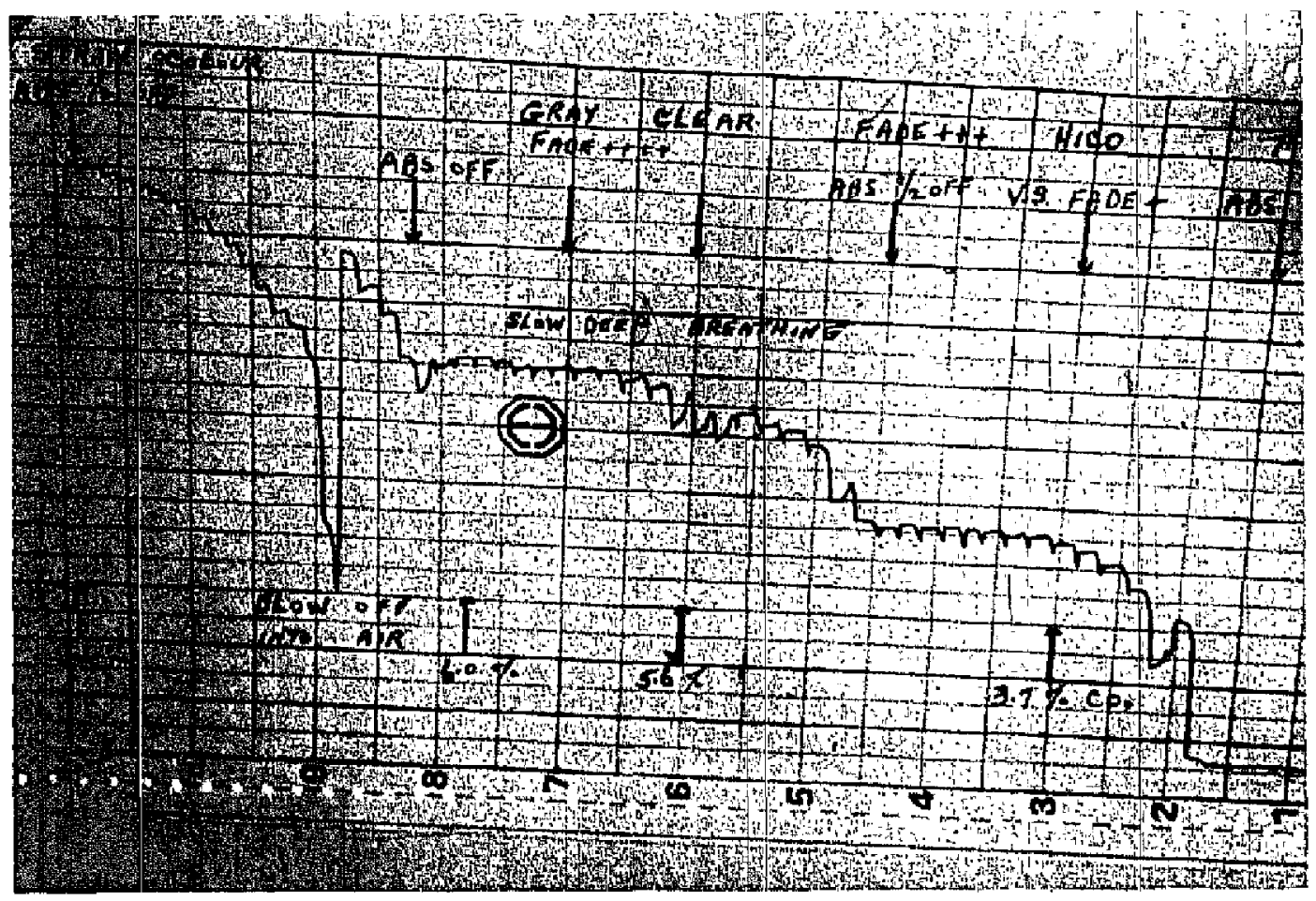

Fucure 4 (Tracing no. 6-1). Inspiratory pattern showing the carban dioxide values in percentages corresponding to changes in colour of the "Hico" detector. "Abs" menns absorber. Tracing starts at the right with the absorber turned ane-third off.

change in this indicator, there may still be very little other clinical evidence of carbon dioxide accumulation. On the other hand, when this indicator dye does fade, we should realize that the levels of carbon dioxide have already risen considerably.

Recently the British Oxygen Company have introduced a somewhat similar chemical carbon dioxide analyser, but we have not had an opportunity to monitor its efficiency.

\section{Tidal: Inspiratory and Expiratory}

During these stuclies we have found tidal sampling to be the most practical as it presented fewer difficulties, and moreover, the most interesting and helpful patterns.

For tidal sampling, the Liston-Becker sampling cell is connected directly to the mask or the endotracheal tube, thus allowing all the respired gases to pass through the analyser (Fig. 5). A comparison between the inspiratory and expiratory levels of carbon dioxide is always available. Consequently, most of our tracings are those obtained by tidal sampling.

\section{Techniques with Candon Digixide Agsomption}

\section{Gas Machines}

The efficiency of carbon dioxide absorption by some type of lime in a gas machine was evaluated in both conscions and anaesthetized subjects. Nine indi- 


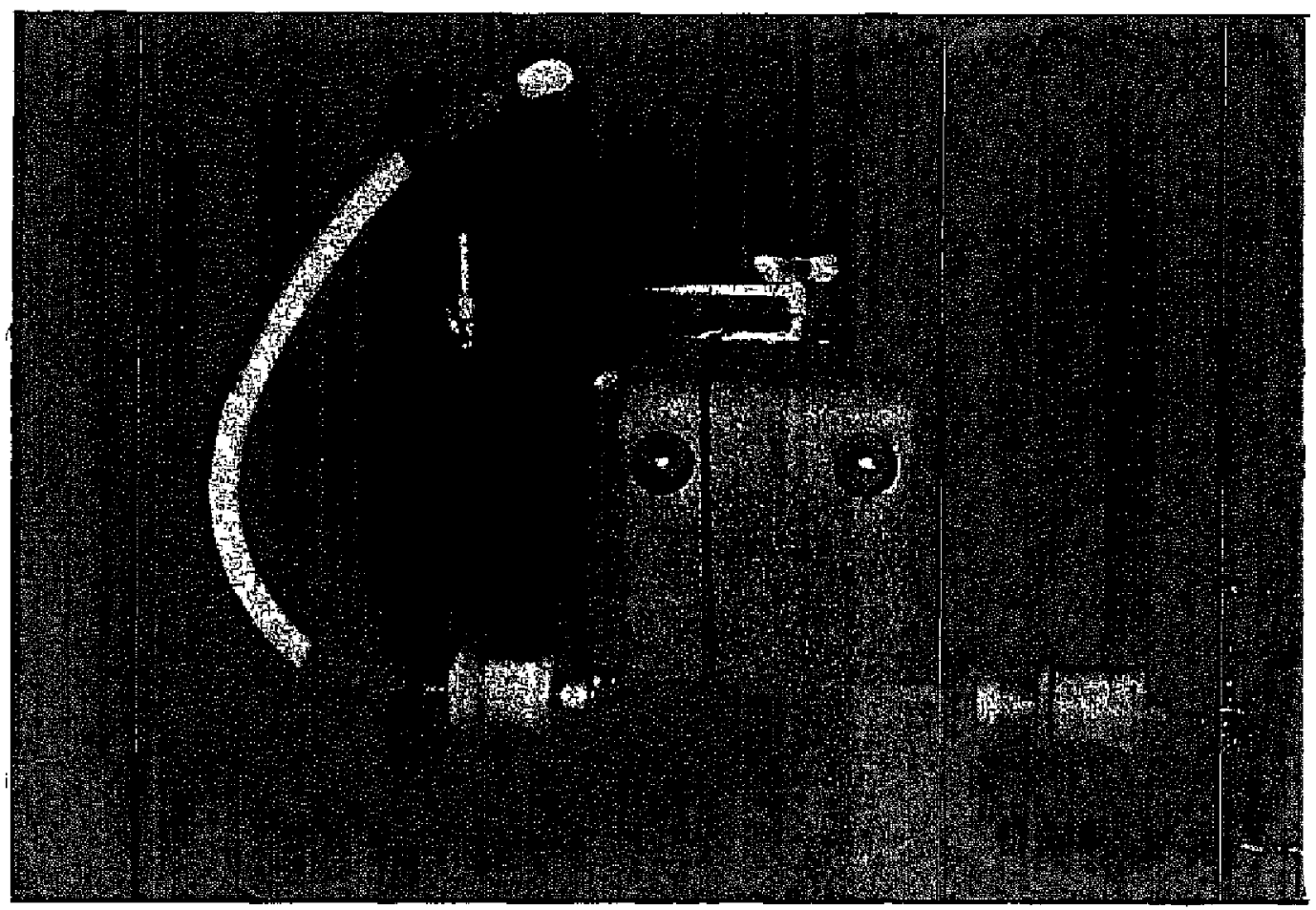

Figure 5 The Liston-Becker sampling cell placed in the circuit for tidal sainpling of inspiratory and expuratory gases

vidual machunes of vanous manufacturers were studied using the same brand of lime in each (Hetdbrunk, Foregger (crrcle and to-and-fro types), Boyle, Loos, Marrett, and Reserve Midget)

We were initally intrigued by the rapidity with which the pattern would change when the absorber was turned off, and agam when it was turned on With the very next breath of the subject, after absorption was stopped, the inspiratory carbon dioxide level sharply rose and continued to rise with each succeeding breath At the same time, the expuatory level very gradually rose, with the result that the two levels soon approached each other The tracing was then only a shallow wavy line at a level of about 9-10 per cent, in the conscious cases

It was an interesting finding that none of the conscious volunteers would tolerate over 10 per cent carbon dioxude One subject, on several tests signalled to have the absorber turned on only when the recorder indicated exactly 10 per cent carbon droxde (24) When the absorber was turned on, the levels rapidly returned to normal ( $F_{1 g} 6$ )

Harbord found "alveolar" carbon droxıde levels dbove 7 per cent in a high proportion of patents, after making over 300 observations ( 22 23)

We were surprised to find the "alveolar" levels in several of our volunteers, when breathing etther aur or oxygen, to be between 70 and 80 per cent (Fıg 7) There is probably a considerable vanation in subjects

Thus there is very good evidence of the efficiency of this method of carbon droxide control In general, all the common machines used by anaesthetists (at 


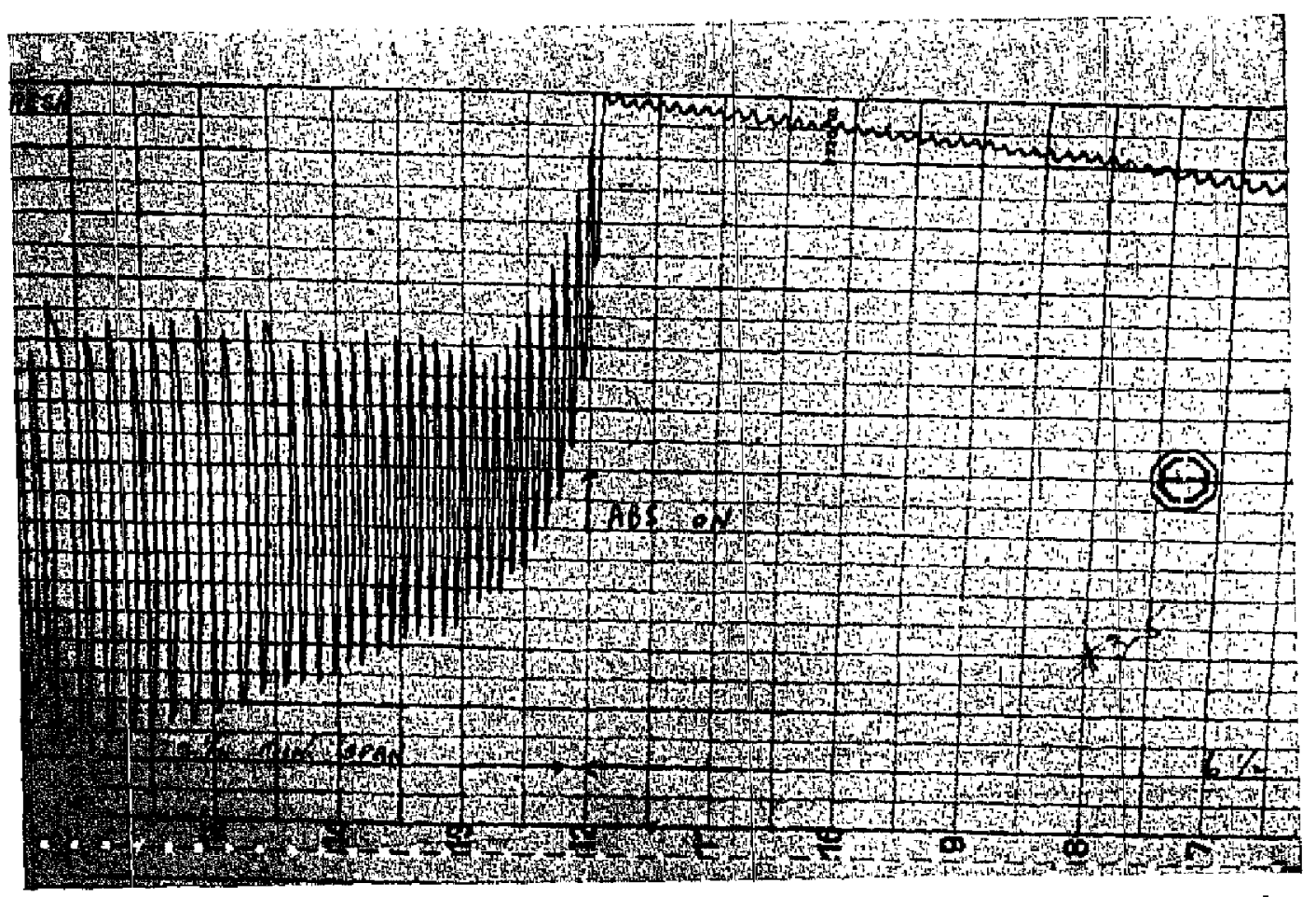

Figune 6 ('Tracing no. 3-5). Carbon dioxide tracing of conscious volumteer with absorber off until the pattern reached the peak which represents 10 per cent carbon dioxide. The lower points of the pattem represent inspiratory levels and the upper points represent expiratory levels of carbon dioxide.

least the particular ones tested) have quite efficient absorption units. However, when a single test pattern was obtained from several machines, changing every minute or two from one to another, quite a variation was obtained. When monitoring absorption efficiency in this way, the inspiratory carbon dioxide levels were most significant. Although most of the patterns were obtained with the subjects breathing oxygen with or without anaesthetic gases, we did obtain a few tracings (not illustrated) when conscious subjects inspired predetermined concentrations of carbon dioxide.

Although most of the absorption units provided consistently comparable patterns indicating efficiency, two units repeatedly provided tracings indicative of a higher degree of efficiency. One machine indicated by $F$ in the tracings produced an inspiratory pattern indistinguishable from that of room air, or from that obtained with a non-rebreathing valve (Fig. 7 ).

On the other hand, one unit persisted in producing a definitely higher inspiratory level of carbon dioxide, but it also gave the conscious patient definite evidence of resistance during inspiration and expiration (Figs, 7 and 8). Further trials with other specimens of this "brand" of machine should be done.

\section{Absorption Lime}

Three different "brands" of lime, provided for anaesthetic machines, were used in these tests. The tracings indicated that each specimen of fresh lime proved to be a good absorber of carbon dioxide when initially used. 


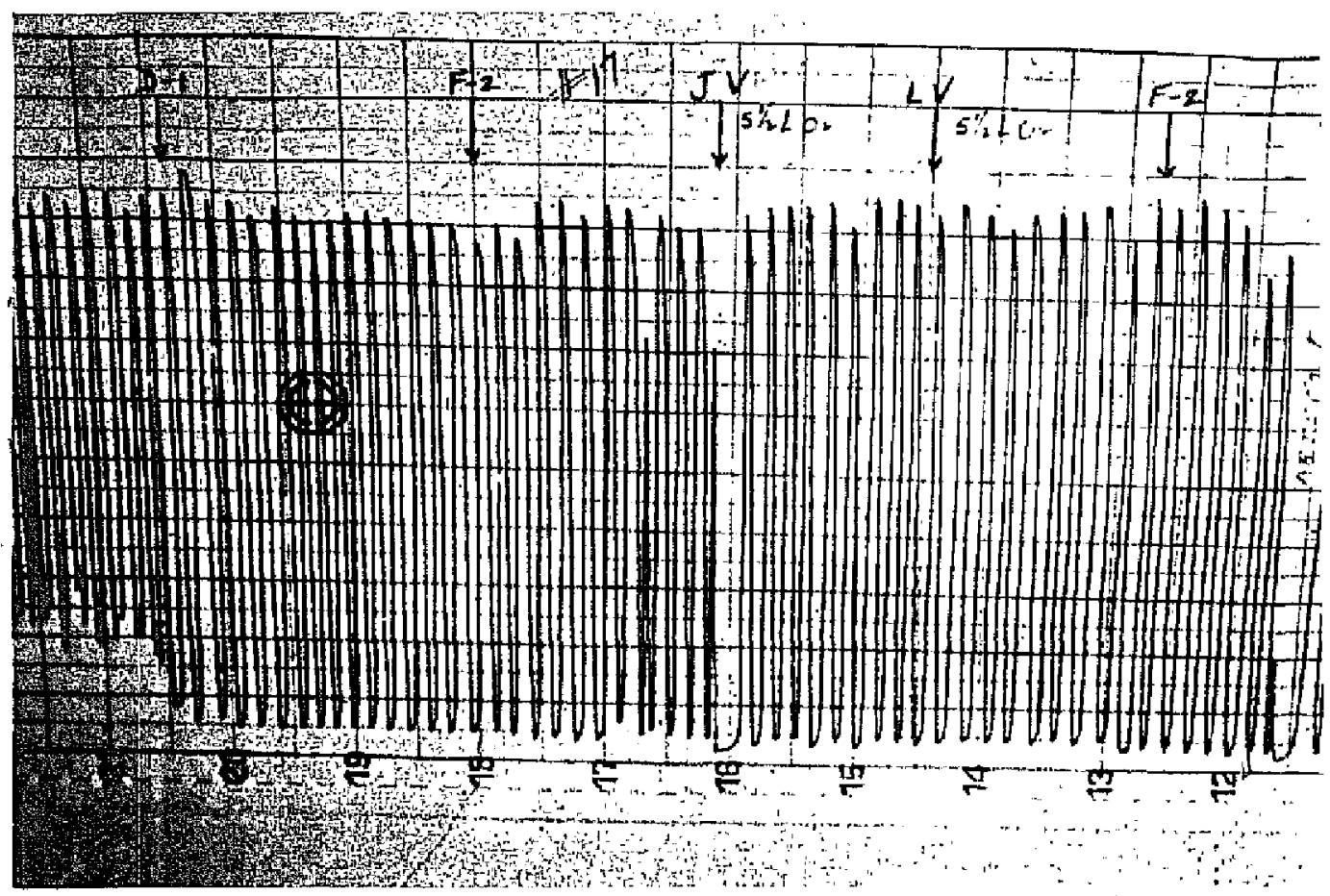

Frcure 7 (Tracing no. 17). Carbon dioxide pattern of conscious volunteer, changing frequently from one gas machine to another. F-2, one machine with closed circle systen with absorption; D-1, another machine with closed to and fro system with absorption; JV, one machine with non-rebreathing valve; $\mathrm{LV}$, another machine with non-rebreathing valve. All, except $\mathrm{D}-1$, produced very good inspiratory levels of carbon dioxide.

It has been reported by Gibbon et al, that lime required frequent changing (every 20-30 minutes) when ventilation was automatically controlled, because of the increase in minute volume. Our short experience with automatically controlled ventilation in this study seemed to bear out this requirement. However, the efficiency of one brand of lime seemed to decline after 2 or 3 minutes with the inspiratory levels, slowly creeping up thercafter. Another brand maintained its efficiency at the initially good level after at least 45 minutes of automatically controlled ventilation (Fig. 9). Thus there may be some variation in the efficiency of lime. We have, as yet, no observations on the efficiency of various limes after prolonged periods of use or after periods of rest. Very wet lime was found to be less efficient than the standard product (Fig. 10).

\section{Techingues wtthott Carkon Dioxide Absorption}

In England there has been for many years, and in Canada more recently, a technique with no absorption of carbon dioxide but rather an intentional partial rebreathing. It is usually referred to as a semi-closed to-and-fro method. It should not be confused with the to-and-fro Water's absorption unit which can also-be used in a semi-closed circuit.

This English inhaler consists of a mask, expiratory valve, single breathing tube, and a small bag attached to the machine. 


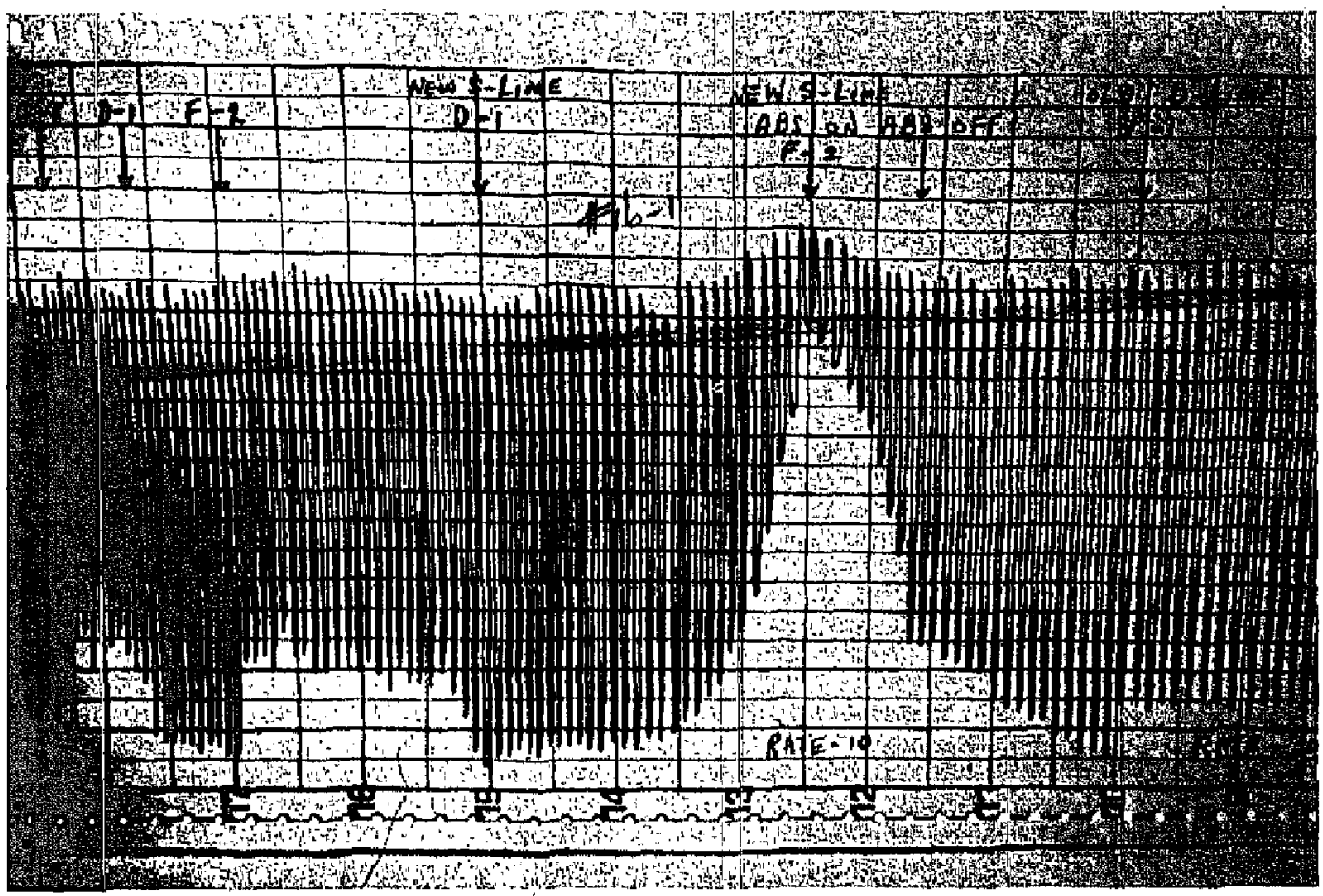

Figuat 8 (Tracing no. 16-1). Carbon dioxide pattern of conscious volunteer with absorption using various limes and various machines and a slow recorder. The lower points of the pattern (inspiratory levels) change with the efficiency of the lime or the machine. As the absorber is on or off the level changes with each breath. Rate of respiration was 10 (as indicated).

It is a very practical unit for the administration of nitrous oxide, oxygen and ether, or trichlorethylene.

In 1946 A. Charles King repeats (25) that "rebreathing is not only economical but physiologically sound in that it prevents the patient suffering from carbon dioxide deficiency." Our tracings, with all methods, indicate that there is never any need of being concerned about carbon dioxide deficiency but rather about an excess.

Some carbon dioxide patterns were obtained in the conscious patient with oxygen, as well, as in the anaesthetized patient with nitrous oxide and oxygen, with or without trichlorethylene (T.C.E.). The Liston-Becker cell was placed at the mask between the latter and the expiratory valve. One tracing was obtained from a patient having sigmoidoscopy under pentothal- $\mathrm{N}_{2} \mathrm{O}-\mathrm{O}_{2}-\mathrm{T} . \mathrm{C} . \mathrm{E}$. anaesthesia with the above technique, using a five-litre hag. The total gas flow was varied from 0.5 litres to 15.0 litres on the machine unit designated J. After a pentothal induction ( $300 \mathrm{mg}$ ), a mixture of 6 litres $\mathrm{N}_{2} \mathrm{O}$ plus 2 litres $\mathrm{O}_{21}$ was started with a small amount of T.C.E. When the total flow was at least 8 litres, quite a good pattern was obtained. However, when it was increased to $9,10,11,13,14$, and 15 litres, no appreciable improvement occurred. But when the total flow was decreased to $7,6,5,4,2,1$ and $1 / 2$ litres, a very definite upward shift in the inspiratory levels occurred at every step, especially below 6 litres. 


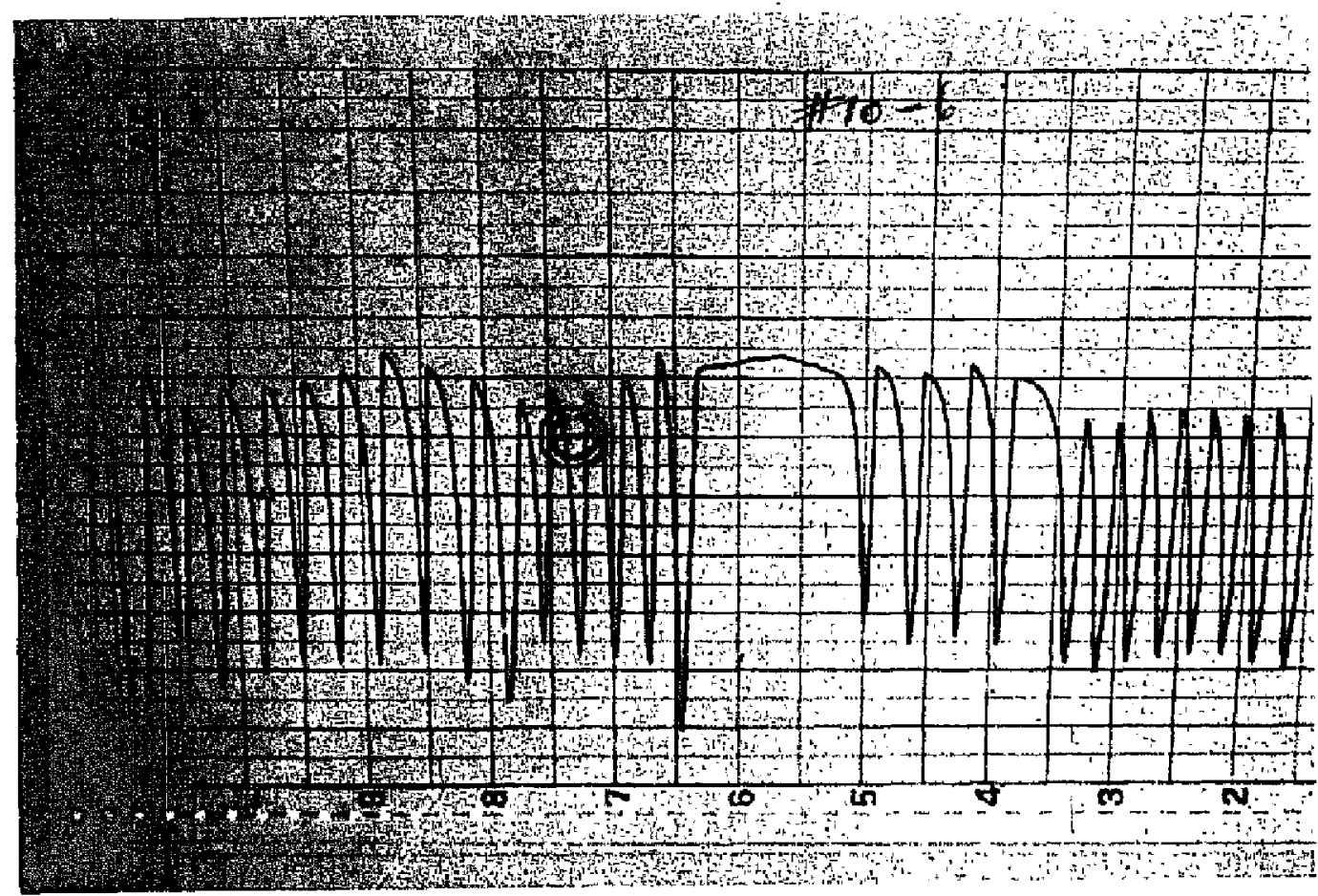

Fugure 9 (Tracing no. 10-6). Pattern in anaesthetized subject compariug M.G.V. (manually controlled ventilation) with A.C.V. (automatically controlled ventilation on Jefferson ventilator); M.C.V. in various degrees of presstere and rhythm from no. 2 to $10 \%$ on tracing. Note the better pattern after A.C.V. is started. Lime used over 45 minutes.

This tracing (not illustrated) is complicated by an increase in respiratory rate unrelated to raised carbon dioxide levels but rather due to T.C.E. This rapid shallow respiration can be shown to be very inefficient when considering carbon dioxide elimination.

Fig. 11 shows the effects of this method when using only oxygen, in a conscious volunteer. The conscious experienced subject soon objects to the expiratory resistance in the circuit. $\mathrm{He}$ is forced to expire against positive pressure a good deal of the time because of the high inflow of gases and the resistance in the expiratory valve. If the bag is suddenly emptied he will quietly and comfortably breathe directly to and from the bag. The tracing will immediately show a sharp rise in carbon dioxide levels and as the pressure builds up, the subject will eventually blow open the expiratory valve with an inner sense of great relief; this is only to be followed soon by another build-up of pressure and carbon dioxide.

If a non-rebreathing valye is used in place of the expiratory valve in such a circuit, the expiratory resistance is immediately removed and the carbon dioxide pattern simulates that obtained with the Liston-Becker cell open to room air (Fig. 7).

\section{Ventulatony Effects on Cahbon Dioxide Levels}

Since it has been shown (2A) that ventilation bears a very direct relationship to the alveolar and arterial levels of carbon dioxide, we cannot stress' too 


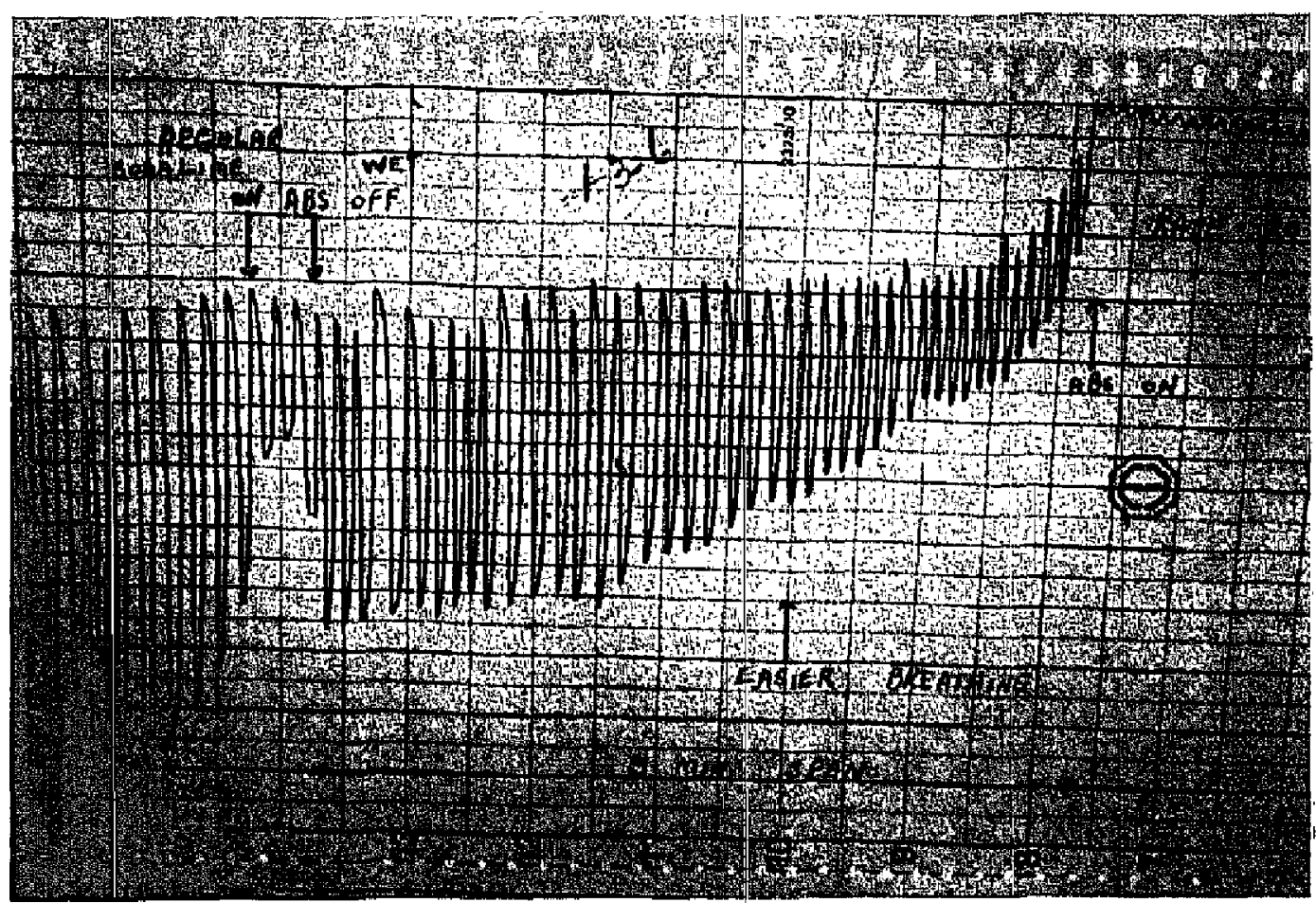

Figure 10 (Tracing no, 3-6). Pattern in conscious volunteer, to be compared with Fig. 6 . At the right the tolerance level of $10 \mathrm{per}$ cent carbon dioxide is reached, while respiratory rate is only 20 per minute. Very wet lime does not return inspiratory levels to normal in a comparable span of time, whereas regular lime is effective.

emphatically the need for adequate ventilation. In clinical anaesthesia, whether you are watching the movements of the chest and abdomen, or feeling the rate, regularity, and force of expiration on the palm of your hand, or seeing or feeling the movements of the breathing bag, how can you judge the adequacy of the ventilation? Do you satisfy yourself by the colour of the skin or blood? Do you compare the ventilation of your anaesthetized patient with that of the same patient you may have observed sleeping in bed on the previous evening? If so, is the extent of the ventilation during sleep adequate for the same patient when anzesthetized? There is no useful clinical evidence of carbon dioxide retention.

It has been known for some time that the total ventilatory minute volume necessary for the prevention of respiratory acidosis in the anaesthetized patient is in excess of that required by the normal unanaesthetized individual. A value two or three times the resting normal values may be required to maintain a normal arterial carbon dioxide tension (15).

Thus we were keenly interested to see the effects on the carbon dioxide tracing of clinically adequate spontaneous ventilation, manually controlled ventilation, and automatically controlled ventilation. The latter was obtained with the Jefferson Ventilator (Fig. 9).

These tracings show very clearly that the automatically controlled ventilation proved consistently uniform inspiratory and expiratory levels, for example, 0.5 per cent and 6.0 per cent respectively. Each time the ventilation was 


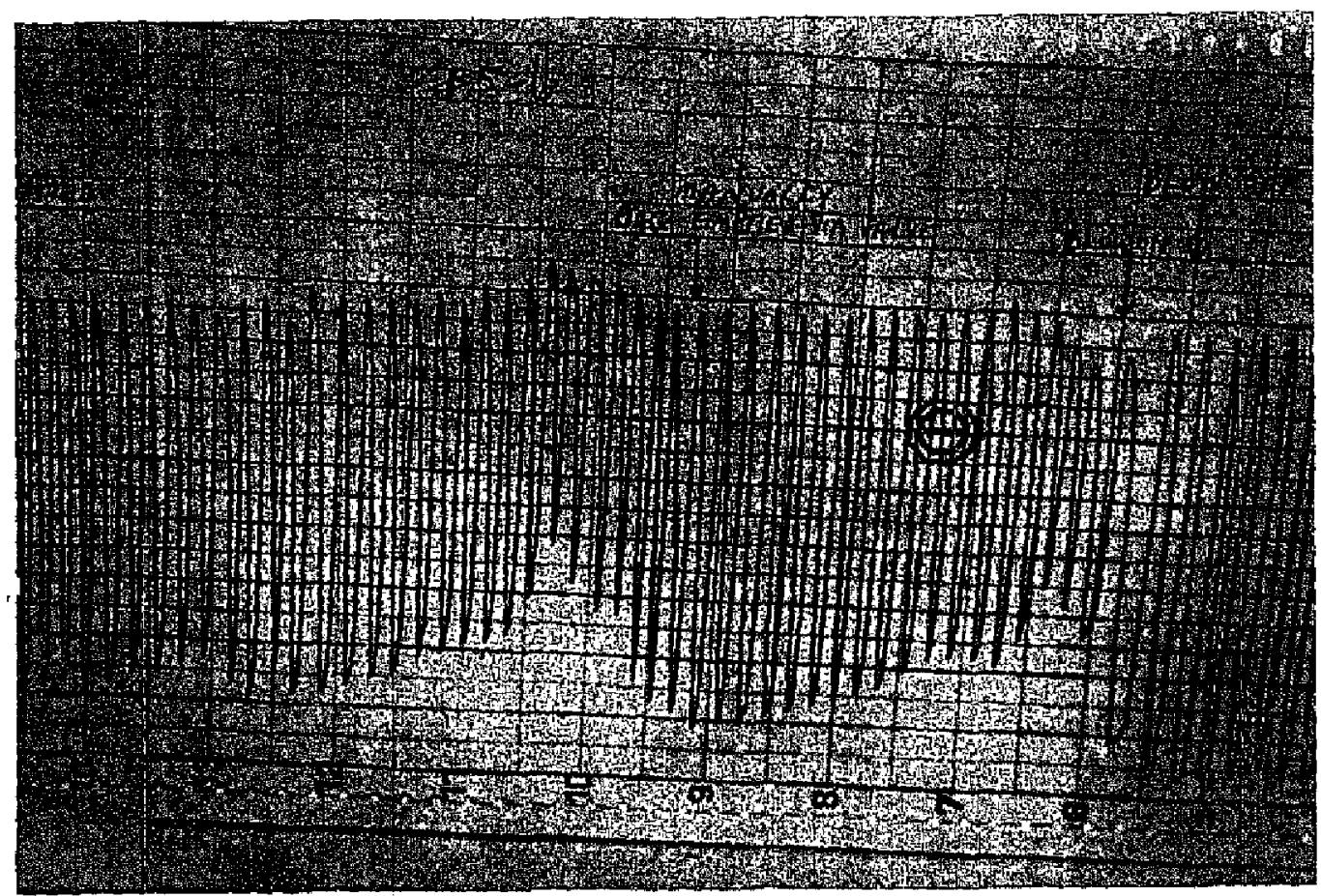

Fioune 11 (Tracing no. 5-6). Conscious volunteer, using semi-slosed techaiqute without absorption, breathing oxygen.

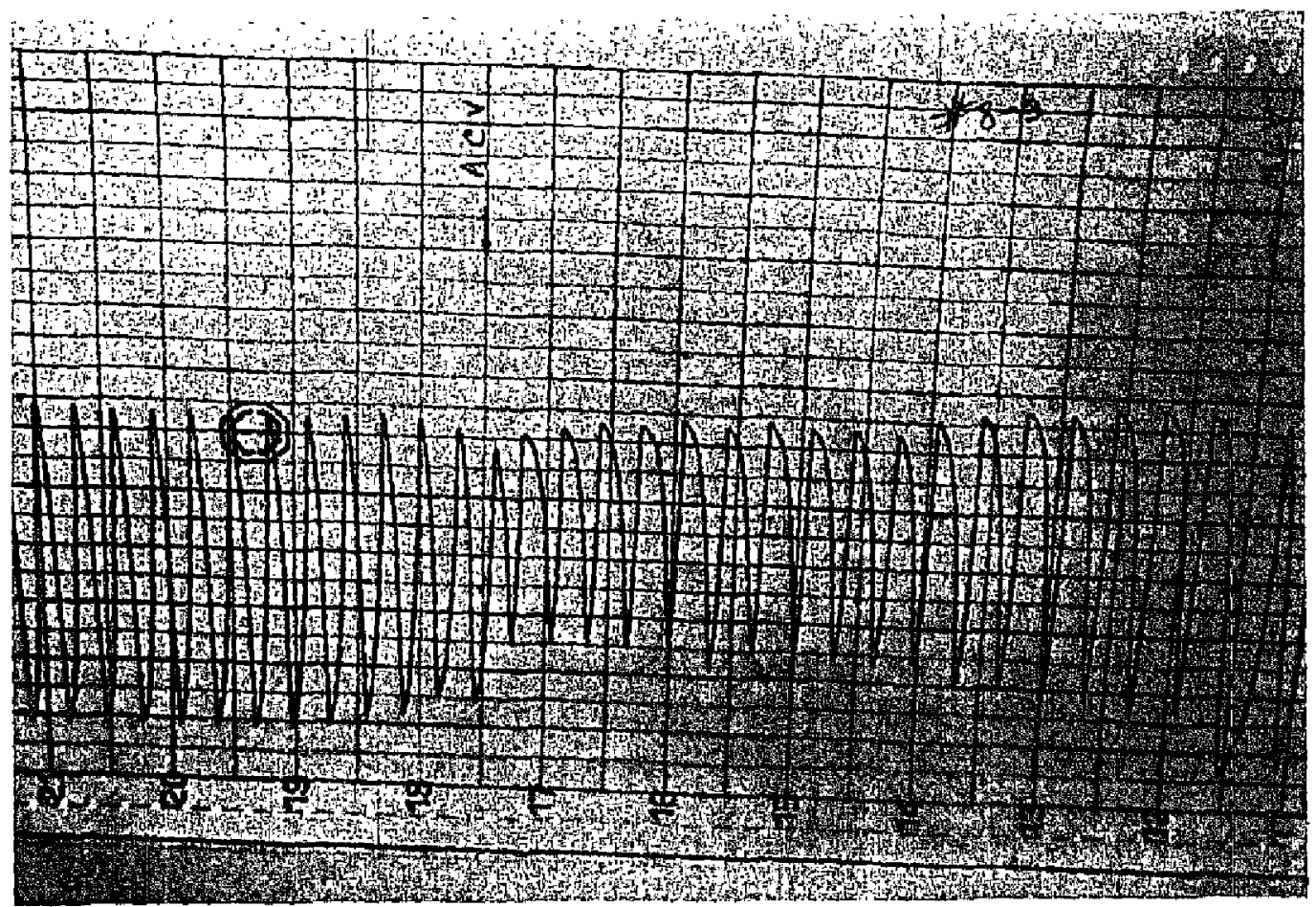

Frcuna 12 (Tracing no. 8-3). Anaesthetized subject showing the lower inspiratory levels when A.C.V. is compared with M.C.V., reading from right to left. 


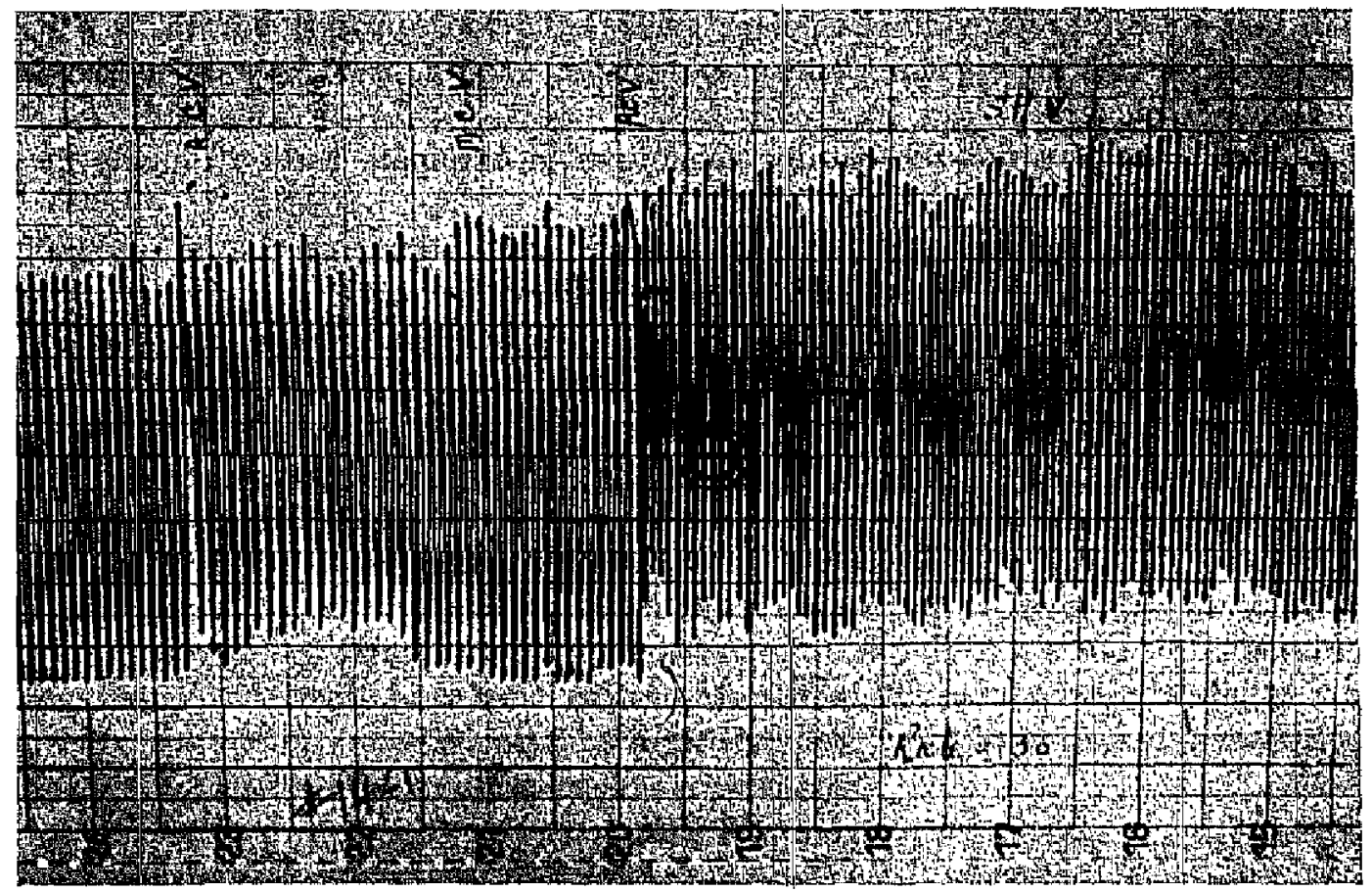

Frguru 13 (Tracing no. 14-1). Anaesthetized subject showing effects of varions types of ventilation, reading from right to left, Respiratory rate is 30 per minute during spontaneous ventilation while A.C.V, rate is 24 .

switched over to manual control, the, efficiency depreciated very, definitely, in spite of the most clinically efficient manner in which any of us could perform the method. Possibly we are not gifted with "educated hands." Thus we were soon convinced of the superior results obtained with the antomatic ventilator. No doubt the effects on the circulation are equally superior, especially when the positive and negative pressures are suitably adjusted to the particular patient (5) (Fig. 12).

Expiratory levels during spontaneous ventilation appear much higher than those obtained by automatically or manually controlled ventilation (Fig. 13). Does this mean that this particular subject is better able to eliminate carbon dioxide from his alveoli by spontaneous ventilation than we are able to do for him by manual or mechanical means? We cannot answer this problem but it leaves a challenging obscrvation with us.

\section{Conclosions}

1. Carbon dioxicle levels in the inspired gas mixture can rise very suddenly and persistently. What is more dangerous and more common is the unsuspected chronic accumulation of carbon dioxide which may develop insidiously. This will jeopardize the ability of the patient to eliminate carbon dioxide (1); especially when he is already depressed by anaesthetic drugs. Gray reminds us that in the anassthetized subject concentrations of carbon dioxide as low as 5 per cent may lose their stimulatory effect and be converted to a depressing one (24).

2. The need for some simple device for detecting carbon dioxide during anaesthetics should be emphasized. 
3. Gas machines providing efficient carbon dioxide absorption are essential for closed circuit anaesthesia. The manufacturer should provide good evidence of such efficiency.

4. The value of a non-rebreathing technique to eliminate carbon dioxide has been clearly shown $(26,27,28,29)$.

5. Anaesthetic techniques which involve any rebreathing or the addition of carbon dioxide should be critically challenged.

6. Effective alveolar ventilation, in addition to oxygenation, should be the insistent objective of every anaesthetst. Should we adopt the motto "V for Ventilation"?

7. Further studies of carbon dioxide levels in the respired gases, as well as in the arterial system, are essential to the progress of anaesthesia.

Professor W. R. Spurrell recently concluded a discussion of carbon dioxide as follows: "We want to put more faith in the respiratory centre, to cherish it and nourish it but not to flog it, to guard its blood supply and its oxygen supply, to regulate the pressures within the respiratory tract and then the centre will look after the carbon dioxide problem itself" (23).

\section{RÉSUMÉ}

Le rôle du gaz carbonique a longuement été discuté. Le gaz carbonique joue un rôle de premier ordre dans le contrôle cle la respiration aussi bien que dans celui de la circulation. Chez lindividu normal, la tension du gaz carbonique dans les liquides de l'organisme ne présente que de légères variantes (1).

Toutefois, au cours de l'anesthésie, il peut arriver que les limites normales soient dépassées. En fait, on rapporte couramment de nos jours des cas d'acidose respiratoire marquée, due à l'accumulation, au cours de l'anesthésie, de grandes quantités de gaz carbonique $(2,3,4,5,6,7,8)$.

Bien que le gaz carbonique soit le principal facteur dans la production de l'acidose, la retention, au cours de l'anesthésie, de certains autres produits du métabolisme peut aussi contribuer à réaliser ce tableau clinique (9). Mettons en lumière l'importance de leur rôle.

L'appareil Liston-Becker, analyseur à infra-rouge, nous a permis d'analyser, par une méthode physique pratique, les atmosphères respirées et de connaître leur contenu en gaz carbonique.

Ainsi nous avons pu observer à tous les instants, à toutes les respirations, à l'inspiration et à l'expiration, le pourcentage de gaz carbonıque présent.

Nous étions intéressés à connaître le pourcentage de gaz carbonique dans l'air inspiré aussi bien que dans l'air expiré au cours des différentes techniques anesthésiques en usage courant $(19,20)$.

Notre méthode ne nous a pas permis seulement d'évaluer les techniques actuelles mais également d'évaluer les différentes machines à anesthésie. Naturellement, nous avons commencé par les méthodes d'absorption dans un but critique. Après, nous avons étudié les différentes substances employées pour absorber le gaz carbonique, c'est-à-dire la variété des sortes de chaux.

La plus grande partie de cette étude, probablement, est consacrée à l'évaluation de l'efficacité de chacune des méthodes de ventilation. Nous avons comparé la 
ventilation spóntanée (Sp. V.) à la ventilation contrôlée à la main (M.C.V.), celle-cı à la ventilation cortrôlée automatiquement (A.C.V.), en prenant comme index d'efficacité, le pourcentage de gaz carbonique dans Pátmosphère expirée.

\section{Conclusions}

1. Le taux de gaz carbonique dans les mélanges de gaz inspirés peut s'élever rapidement et de façon continuelle. Ce qu'il y a de plus!dangereux et de plus fréquent, c'est l'accumulation chronique et insoupçonnée du gaz carbonique qui peut survenir insidieusement. Elle peut compromettre, pour le malade, la possibilité d'éliminer son gaz carbonique (1), surtout s'il est déprimé par les agents anesthésiques. Gray nous rappelle que, chez des sujets anesthésiés, des concentrations de gaz carbonique aussi basses que 5 pour-cent peuvent perdre leurs effets stimulants et acquérir des effets dépresseurs (24).

2. Il faudrait insister sur la nécessité de trouver un procédé simple pour doser le gaz carbonique au cours des anesthésies.

3. Pour faire de l'anesthésie en circuit fermé, il est essentiel d'avoir des machines assurant une absorption efficace. Les manufacturiers devraient pouvoir prouver l'efficacité d'absorption de leurs machines.

4. La valeur de la technique de non-réinspiration pour éliminer le gaz carbonique a été clairement démontrée $(26,27,28,29)$.

5. Il faut se défier des techniques d’anesthésie où il existe une certaine réinspiration, ou encore, où il y a une addition de gaz carbonic ue.

6. En plus de loxygénation, la ventilation alvéolaire eff cace devrait être l'objectif constant de tous les anesthésistes. Ne devrions-nous pas adopter le motto "V pour Ventilation"?

7. Il est essentiel, pour le progrès de l'anesthésie, que soit poursuivie l'étude des taux de gaz carbonique dans l'air inspiré aussi bien que dans le sang artériel.

Récemment, à la suite d'une discussion sur le gaz carbonique, le Professeur W. R. Spurrell concluait ainsi: "Nous voulons augmenter notre confiance dans le centre respiratoire, nous voulons en prendre soin et le nourrir et non jas le fouetter ${ }_{4}$ nous voulons lui conserver ses réserves de sang et d'oxygène, njus voulons régler les pressions dans les voies respiratoires et, alors, le centre respiratoire soccupera lui-même du problème du gaz carbonique" (23).

\section{REFERENCES}

1. Goodman \& Grman The Pharmacological Basis of Therapeutacs, p 917. 2nd ed, 1955.

2 BeEcher, H. K. \& MURPhY, A. J. J. Thoracic Surg. 19: 50 (1950),

3. Etstein, B. E. J. Thoracic Surg. 25: 286 (1953).

4. GabBard, J. G. et al. Ann. Surg. 136: 680 (1952).

5. Gimbon, J. H. et al. Ann. Surg. 132: 611 (1950).

6. WATERS, R M. New Orleans M \& S. J 90. 219 (1937).

7. Eluison, R. G. et al. Ann. Surg. 141. 375 (1955)

8. Stzad, W. W. et al. J. Thoracic Surg. 27: 306 (1954).

9. GinJIEs, Jorrn. Personal communication (1955)

10. Bourne, W. To be published.

11. Martin, F. E., Stead, W. W. et al. J Thoracic Surg 29: 327 (1955).

12. Brindle, G. F., \& Cullen, W. G. To be published.

13. Heard, Kenneth. Personal communication (1945). 
14. Collier, C. R J Lab. \& Clin. Med 45526 (1955).

15. Morris, Lucien E. Proc. Can. Anaes Soc , 65 (19.53).

16. Davis, D A et al. Anesthesiology 16333 (1955).

17 PASK, E A. Personal communication (1955)

18. PAsk, E. A. Anaesthesia 104 (1955)

19. Schwartz, C H et al Anesthesiology 14437 (1953)

20 Harrison, G G \& Jones, C S Brit J Anaesth, 27162 (1955)

21 Draper, W B \& Longwell, B B Colorado Med 32899 (1935)

22 Harbond, R P. et al Proc. Roy. Soc. Med 46. 365 (1953).

23 Spurreld, W. R Proc Roy Soc. Med 48 231 (1955)

24 Gray, JoHN S Pulmonary Ventılation, pp 29-37 C C Thomas (1950).

25. King, A Charles Principles of Gaseous Anaesthetic Apparatus, p 27 2nd ed, 1946.

26 Bulxougr, Jorn Brit. J. Anaesth. 27181 (1955)

27 LeIgh, M. D \& Kester, H A Anesthesiology 15 L07 (1948)

28 Slater, H M \& STEPHEN, C. R Arch Surg 62251 (1951)

29 Smrth, R T Anesthesiology 14107 (1954)

30 Eastwood, A B \& Harbord, R P Anaesthesia 1034 (1955) 